\title{
The effects of vitamin C-polyethylene glycol complex on growth performance and immunity in broiler chickens*
}

\author{
T.-W. Hahn' ${ }^{1}$ J.D. Lohakare', Y.H. Shim ${ }^{1}$, K.N. Han ${ }^{1}$, H.K. Won ${ }^{1}$, \\ Y.H. Park ${ }^{2}$ and B.J. Chae ${ }^{1,3}$
}

\author{
${ }^{1}$ College of Animal Resources, Kangwon National University \\ Chunchon 200-701, Korea \\ ${ }^{2}$ College of Veterinary Medicine, Seoul National University \\ Seoul 151-742, Korea
}

(Received 30 June 2004; revised version 26 July 2004; accepted 31 January 2005)

\begin{abstract}
This research was conducted to evaluate the efficacy of vitamin C-polyethylene glycol complex (VCPEG) in broiler chickens during heat stress. For a 6-week feeding trial, a total of 330 broiler chickens were allotted to five dietary treatments. The dietary vitamin C (VC) levels (treatments) were, $\mathrm{mg} / \mathrm{kg}$ : 1. $0 \mathrm{VC}$ (negative control), 2. $200 \mathrm{VC}$ as ascorbate (positive control), 3. $10 \mathrm{VC}-\mathrm{PEG}, 4$. $20 \mathrm{VC}-\mathrm{PEG}$, and 5. 50 VC-PEG. At the end of the experiments nine chickens per treatment were sacrificed for the analyses of VC contents in blood and liver, and meat quality. During the starter period, chickens on negative control group (no VC added) grew slower $(\mathrm{P}<0.05)$ than others. During the overall period, chickens fed diets containing 20,50 mg/kg VC-PEG, and $200 \mathrm{mg} / \mathrm{kg}$ ascorbate showed improved weight gain $(\mathrm{P}<0.05)$ than those fed 0 or $10 \mathrm{mg} / \mathrm{kg}$ VC-PEG. VC concentrations in plasma and liver were higher in chickens fed diets with vitamin $\mathrm{C}$. Bone strength was also higher (linear, $\mathrm{P}=0.001$ ) as dietary $\mathrm{VC}$ level was increased. There was no effect on lymphocyte sub-population. Antibody response to Newcastle disease and infectious bronchitis vaccination was higher in $20 \mathrm{mg} / \mathrm{kg}$ VC-PEG fed group as compared with other VC-PEG groups. In conclusion, $\mathrm{VC}$ supplementation was beneficial to broilers during heat stress.
\end{abstract}

KEY WORDS: vitamin C, growth, immunity, broiler, bone, polyethylene glycol

\footnotetext{
* Supported by LG Life Sciences Ltd., Seoul, Korea

${ }^{3}$ Corresponding author: e-mail: bjchae@kangwon.ac.kr
} 


\section{INTRODUCTION}

Poultry has the ability to synthesize ascorbic acid in their body (McDowell, 2000), and hence there is no recommended requirement established by the NRC (1994). However, environmental and pathological stressors are known to alter ascorbic acid utilization and/or synthesis in the fowl (Pardue and Thaxton, 1986). The chicken is subject to considerable stress conditions, such as rapid growth, exposure to hot or cold temperatures, vaccinations, and diseases in the field condition. High temperature led to reduced growth rate and increased mortality in broilers (Pardue et al., 1985), so it is one of the major concerns in broiler production.

Several researchers observed significant improvement in growth of chickens by the addition of vitamin C (VC) under high temperature (Thaxon and Pardue, 1984; Kassim and Norziha, 1995). It was observed that broilers fed diets containing VC were less stressed by reduced body temperature and respiratory rates (Pardue and Thaxon, 1986; Kassim and Norziha, 1995) and showed increased feed intake (Kutlu and Forbes, 1993; Mckee and Harrison, 1995) than the control birds (no VC).

On the other hand, ascorbic acid is very susceptible to destruction through oxidation (McDowell, 2000). So, coated product is available to improve its stability in the feed. One of the methods to improve the stability is to combine it with other materials like polyethylene glycol. VC-polyethylene glycol complex (VC-PEG) is known to be more stable than any other VC sources during storage at room temperature. This VC-PEG compound was proven to show higher bioavailability and growth promoting effects (LG Chemicals Report, 2000).

Previous substantial reports suggest that under field conditions, treating VC may enhance productivity, immune response, disease resistance, and survivability under stressful conditions (Pardue et al., 1985; Gross, 1988; Zulkifli et al., 1996). The purpose of this experiment was to evaluate the efficacy of the $\mathrm{VC}$ in polyethylene glycol complex form on broiler's growth performance and immunity during summer season in Korea.

\section{MATERIAL AND METHODS}

The design, birds, sample preparation, chemical and statistical analyses remained the same as explained in detail in vitamin-E polyethylene glycol experiment conducted in parallel with this experiment (Chae et al., 2005). The difference was only in the dietary treatments as the dietary VC levels were, $\mathrm{mg} / \mathrm{kg}: 1.0$ (negative control), 2. 200 ascorbate (positive control), 3. 10 VC-PEG, 4. $20 \mathrm{VC}-\mathrm{PEG}$, and 5. $50 \mathrm{VC}-\mathrm{PEG}$. 
The room temperature was also measured after every four hour during the whole experimental period. The vitamin premix used in the control and experimental group in this study contain vitamin E at $10 \mathrm{mg} / \mathrm{kg}$ feed. Also after slaughter blood and liver samples were taken to analyse VC contents. Rest experimental procedure remained the same.

TABLE 1

Formula and chemical composition of experimental diets for feeding trial

\begin{tabular}{lcc}
\hline Indices & Starter $(0-3 \mathrm{wk})$ & Finisher $(4-6 \mathrm{wk})$ \\
\hline Ingredients, $\%$ & & \\
maize & 56.06 & 59.90 \\
soyabean meal (44\% CP) & 22.44 & 20.76 \\
maize gluten meal & 7.00 & 8.00 \\
fish meal & 6.16 & 3.00 \\
animal fat & 6.00 & 5.70 \\
tricalcium phosphate & 0.92 & 1.12 \\
limestone & 0.59 & 0.87 \\
vitamin premix & 0.10 & 0.10 \\
trace mineral premix ${ }^{2}$ & 0.20 & 0.20 \\
salt & 0.25 & 0.25 \\
L-lysine HCl & - & 0.03 \\
DL-methionine $(50 \%)$ & 0.20 & - \\
choline chloride $(25 \%)$ & 0.08 & 0.07 \\
Chemical composition, $\%$ & & \\
ME, kcal/kg & 3200 & 3200 \\
crude protein & 22.0 & 20.3 \\
Ca & 0.90 & 0.90 \\
available P & 0.40 & 0.35 \\
lysine & 1.14 & 1.00 \\
methionine & 0.53 & 0.40 \\
methionine + cystine & 0.90 & 0.75 \\
\hline
\end{tabular}

${ }^{1}$ supplied per kg diet, IU: vit. A 9,000, vit. $\mathrm{D}_{3} 1,800 ; \mathrm{mg}$ : vit. E 10 , vit. $\mathrm{B}_{1} 1$, vit. $\mathrm{B}_{2} 10$, vit. $\mathrm{B}_{6} 4$, vit. $\mathrm{B}_{12} 0.02$, vit. $\mathrm{K}_{3} 1$, pantothenic acid 12 , niacin 30 , biotin 0.03 , folic acid 0.5 , ethoxyquin 3 ,

${ }^{2}$ supplied per kg diet, mg: Fe 80, Cu 80, Zn 100, Mn 120, I 2, Co 0.1, Se 0.2

\section{RESULTS}

Growth performance of broiler chickens as affected by dietary VC levels is presented in Table 2. During the starter period, chickens in negative control group (no $\mathrm{VC}$ added) grew slower $(\mathrm{P}<0.05)$ than others. Feed intake was also reduced $(\mathrm{P}<0.05)$ in chickens fed the negative control diet compared to others except $10 \mathrm{mg} / \mathrm{kg}$ VC-PEG fed group. Resultantly, there were linear effects on weight gain $(\mathrm{P}=0.03)$. 
TABLE 2

The effect of supplemental vitamin $\mathrm{C}$ on growth performance in broilers

\begin{tabular}{|c|c|c|c|c|c|c|c|}
\hline \multirow{2}{*}{ Treatments, mg/kg } & \multicolumn{2}{|c|}{ Vitamin C } & \multicolumn{3}{|c|}{ Polyethylene glycol-C } & \multirow{2}{*}{$\mathrm{SE}^{1}$} & \multirow{2}{*}{$\frac{\text { P-value }}{\text { Linear }}$} \\
\hline & 0 & 200 & 10 & 20 & 50 & & \\
\hline \multicolumn{8}{|l|}{ Starter (0-3 weeks) } \\
\hline weight gain, $g$ & $477^{\mathrm{b}}$ & $541^{\mathrm{a}}$ & $503^{\mathrm{ab}}$ & $515^{\mathrm{ab}}$ & $520^{\mathrm{a}}$ & 27.8 & 0.03 \\
\hline feed intake, $g$ & $939^{\mathrm{c}}$ & $1131^{\mathrm{a}}$ & $1006^{\mathrm{bc}}$ & $1038^{\mathrm{ab}}$ & $1061^{\mathrm{ab}}$ & 78.8 & 0.01 \\
\hline feed:gain & 1.97 & 2.09 & 2.01 & 2.02 & 2.04 & 0.13 & $\mathrm{NS}^{2}$ \\
\hline \multicolumn{8}{|l|}{ Finisher (4-6 weeks) } \\
\hline weight gain, $g$ & 898 & 990 & 928 & 947 & 970 & 55.9 & NS \\
\hline feed intake, $g$ & 2288 & 2399 & 2409 & 2430 & 2255 & 310 & NS \\
\hline feed:gain & 2.57 & 2.42 & 2.59 & 2.56 & 2.34 & 0.33 & NS \\
\hline \multicolumn{8}{|l|}{ Overall (0-6 weeks) } \\
\hline weight gain, $g$ & $1375^{b}$ & $1532^{\mathrm{a}}$ & $1431^{\mathrm{ab}}$ & $1462^{\mathrm{a}}$ & $1491^{\mathrm{a}}$ & 71.7 & 0.03 \\
\hline feed intake, $g$ & 3227 & 3530 & 3415 & 3468 & 3316 & 331 & NS \\
\hline feed:gain & 2.36 & 2.30 & 2.38 & 2.37 & 2.23 & 0.22 & NS \\
\hline Mortality, \% & 12.1 & 1.52 & 6.06 & 1.52 & 1.52 & & \\
\hline
\end{tabular}

Dietary VC levels did not affect weight gain and feed intake during finisher period. During the overall period, chickens fed diets containing $20,50 \mathrm{mg} / \mathrm{kg}$ VC-PEG and $200 \mathrm{mg} / \mathrm{kg} \mathrm{VC}$ showed improved weight gain $(\mathrm{P}<0.05)$ than those fed $0 \mathrm{mg} / \mathrm{kg} \mathrm{VC}$. No differences were found in feed intake and $\mathrm{F} / \mathrm{G}$ among dietary treatments.

In the nutrient digestibility, energy digestibility was not different among treatments both in starter and finisher diets (Table 3). However, the digestibilities of protein and ether extract were higher $(\mathrm{P}<0.05)$ in $50 \mathrm{mg} / \mathrm{kg} \mathrm{VC-PEG}$ and $200 \mathrm{mg} /$ $\mathrm{kg} \mathrm{VC}$ groups than others during starter phase. Protein digestibility in the finisher diet was lower $(\mathrm{P}<0.05)$ in $0 \mathrm{mg} / \mathrm{kg} \mathrm{VC}$ group than others, while no difference was found in fat digestibility among treatments.

Bone strength was higher linearly $(\mathrm{P}=0.0001)$ as dietary $\mathrm{VC}$ level was increased (Table 4). Ash contents in 20 and $50 \mathrm{mg} / \mathrm{kg} \mathrm{VC-PEG} \mathrm{fed} \mathrm{groups} \mathrm{were}$ higher $(\mathrm{P}<0.05)$ than $0 \mathrm{mg} / \mathrm{kg} \mathrm{VC}$ group. Calcium and phosphorus contents in tibia from chickens fed diets containing $\mathrm{VC}$ were higher than control, though it was not statistically significant.

As shown in Table 5, there were no differences in dressing percentage, breast meat and abdominal fat percent among treatments. In chicken meat colours, ' $a$ ' value (redness) was significantly $(\mathrm{P}=0.03$ ) increased, and ' $\mathrm{b}$ ' value (brownness) was linearly $(\mathrm{P}=0.001)$ decreased as dietary $\mathrm{VC}$ level was increased in the diet.

$\mathrm{VC}$ concentrations in plasma and liver were higher in chickens fed diets added the vitamin, showing linear effects ( $\mathrm{P}=0.02$ for plasma and $\mathrm{P}=0.05$ for liver) (Table 6 ). 
TABLE 3

The effect of supplemental vitamin $\mathrm{C}$ on nutrient digestibility in broilers, $\%$

\begin{tabular}{|c|c|c|c|c|c|c|c|}
\hline \multirow{2}{*}{ Treatments, $\mathrm{mg} / \mathrm{kg}$} & \multicolumn{2}{|c|}{ Vitamin C } & \multicolumn{3}{|c|}{ Polyethylene glycol-C } & \multirow{2}{*}{$\mathrm{SE}^{1}$} & \multirow{2}{*}{$\frac{\text { P-value }}{\text { Linear }}$} \\
\hline & 0 & 200 & 10 & 20 & 50 & & \\
\hline \multicolumn{8}{|l|}{ Starter (0-3 wk) } \\
\hline gross energy & 76.2 & 78.0 & 77.8 & 77.8 & 78.0 & 1.27 & $\mathrm{NS}^{2}$ \\
\hline crude protein & $72.1^{\mathrm{b}}$ & $77.1^{\mathrm{a}}$ & $73.2^{b}$ & $74.4^{\mathrm{ab}}$ & $76.5^{\mathrm{a}}$ & 2.33 & 0.00 \\
\hline ether extract & $67.2^{\mathrm{c}}$ & $73.7^{\mathrm{a}}$ & $67.7^{\mathrm{c}}$ & $68.9^{c}$ & $71.7^{\mathrm{b}}$ & 2.29 & 0.00 \\
\hline \multicolumn{8}{|l|}{ Finisher (4-6 wk) } \\
\hline gross energy & 77.0 & 79.4 & 77.3 & 77.8 & 79.4 & 1.97 & NS \\
\hline crude protein & $74.2^{\mathrm{b}}$ & $78.9^{\mathrm{a}}$ & $77.4^{\mathrm{a}}$ & $77.5^{\mathrm{a}}$ & $78.0^{\mathrm{a}}$ & 1.93 & 0.01 \\
\hline ether extract & 68.7 & 72.4 & 69.3 & 71.0 & 71.4 & 2.50 & NS \\
\hline
\end{tabular}

TABLE 4

The effect of supplemental vitamin $\mathrm{C}$ on bone resistance and composition in broilers

\begin{tabular}{|c|c|c|c|c|c|c|c|}
\hline \multirow{2}{*}{ Treatments, $\mathrm{mg} / \mathrm{kg}$} & \multicolumn{2}{|c|}{ Vitamin C } & \multicolumn{3}{|c|}{ Polyethylene glycol-C } & \multirow{2}{*}{$\mathrm{SE}^{1}$} & \multirow{2}{*}{$\frac{\text { P-value }}{\text { Linear }}$} \\
\hline & 0 & 200 & 10 & 20 & 50 & & \\
\hline Bone resistance, $\mathrm{kg}$ & $17.3^{\mathrm{c}}$ & $27.7^{\mathrm{a}}$ & $21.7^{\mathrm{b}}$ & $25.8^{\mathrm{a}}$ & $26.5^{\mathrm{a}}$ & 4.06 & 0.00 \\
\hline \multicolumn{8}{|l|}{ Bone composition, $\%$} \\
\hline dry matter & 76.2 & 76.3 & 76.7 & 76.9 & 77.0 & 1.62 & $\mathrm{NS}^{2}$ \\
\hline crude ash & $46.2^{\mathrm{b}}$ & $50.6^{\mathrm{ab}}$ & $54.9^{\mathrm{ab}}$ & $55.8^{\mathrm{a}}$ & $56.9^{\mathrm{a}}$ & 5.56 & 0.01 \\
\hline calcium & 17.0 & 17.9 & 19.9 & 18.3 & 19.8 & 3.56 & NS \\
\hline phosphorus & 7.86 & 8.48 & 8.56 & 8.35 & 8.49 & 0.41 & NS \\
\hline
\end{tabular}

abc values with different superscripts in the same row differ significantly $(\mathrm{P}<0.05)$

${ }^{1}$ pooled standard errors, $\mathrm{n}=9$ birds/treatment

${ }^{2}$ not significant

TABLE 5

The effect of supplemental vitamin $\mathrm{C}$ on chicken meat quality in broilers

\begin{tabular}{|c|c|c|c|c|c|c|c|}
\hline \multirow{2}{*}{ Treatments, $\mathrm{mg} / \mathrm{kg}$} & \multicolumn{2}{|c|}{ Vitamin C } & \multicolumn{3}{|c|}{ Polyethylene glycol-C } & \multirow{2}{*}{$\mathrm{SE}^{1}$} & \multirow{2}{*}{$\frac{\text { P-value }}{\text { Linear }}$} \\
\hline & 0 & 200 & 10 & 20 & 50 & & \\
\hline \multicolumn{8}{|l|}{ Carcass traits, $\%$} \\
\hline dressing percentage & 78.2 & 75.2 & 74.3 & 73.9 & 75.6 & 2.68 & $\mathrm{NS}^{2}$ \\
\hline breast meat & 13.4 & 12.3 & 13.1 & 13.3 & 12.6 & 1.00 & NS \\
\hline abdominal fat & 3.45 & 2.73 & 2.69 & 2.93 & 2.73 & 0.58 & NS \\
\hline \multicolumn{8}{|l|}{ Meat colour } \\
\hline $\mathrm{L}$ & 57.9 & 57.4 & 60.0 & 59.5 & 58.4 & 1.70 & NS \\
\hline $\mathrm{a}$ & $9.9^{\mathrm{b}}$ & $11.8^{\mathrm{ab}}$ & $11.2^{\mathrm{ab}}$ & $10.1^{\mathrm{b}}$ & $12.8^{\mathrm{a}}$ & 1.54 & 0.03 \\
\hline $\mathrm{b}$ & $8.55^{\mathrm{a}}$ & $6.06^{\mathrm{b}}$ & $9.21^{\mathrm{a}}$ & $9.24^{\mathrm{a}}$ & $6.83^{\mathrm{b}}$ & 1.42 & 0.00 \\
\hline
\end{tabular}

${ }^{\mathrm{ab}}$ values with different superscripts in the same row differ significantly $(\mathrm{P}<0.05)$

${ }^{1}$ pooled standard errors, $n=9$ birds/treatment

${ }^{2}$ not significant 
TABLE 6

Effect of dietary vitamin $\mathrm{C}$ on plasma and liver vitamin $\mathrm{C}$ concentration in broilers

\begin{tabular}{|c|c|c|c|c|c|c|c|}
\hline \multirow{2}{*}{ Treatments, $\mathrm{mg} / \mathrm{kg}$} & \multicolumn{2}{|c|}{ Vitamin C } & \multicolumn{3}{|c|}{ Polyethylene glycol-C } & \multirow{2}{*}{$\mathrm{SE}^{1}$} & \multirow{2}{*}{$\frac{\text { P-value }}{\text { Linear }}$} \\
\hline & 0 & 200 & 10 & 20 & 50 & & \\
\hline Plasma, ppm & $7.6^{b}$ & $13.7^{\mathrm{a}}$ & $10.7^{\mathrm{ab}}$ & $12.8^{\mathrm{a}}$ & $13.8^{\mathrm{a}}$ & 2.75 & 0.02 \\
\hline Liver, ppm & 28.9 & 47.3 & 51.3 & 54.8 & 53.5 & 9.24 & NS \\
\hline
\end{tabular}

${ }^{\mathrm{ab}}$ valules with different superscripts in the same row differ significantly $(\mathrm{P}<0.05)$

${ }^{1}$ pooled standard errors, $\mathrm{n}=9$ birds/treatment

${ }^{2}$ not significant

The percentage of CD4, CD8, TCR1, TCR2, and B cells were not affected significantly by VC treatment (Table 7). However, the percentages of CD4 lymphocytes tended to increase with increasing levels of dietary VC supplementation. Apparently, dietary VC supplementation had no effect upon the immune cell populations in chickens.

TABLE 7

The effect of supplemental vitamin $\mathrm{C}$ on lymphocyte sub-population

\begin{tabular}{|c|c|c|c|c|c|c|c|}
\hline \multirow{2}{*}{ Treatments, $\mathrm{mg} / \mathrm{kg}$} & \multicolumn{2}{|c|}{ Vitamin C } & \multicolumn{3}{|c|}{ Polyethylene glycol -C } & \multirow{2}{*}{$\mathrm{SE}^{1}$} & \multirow{2}{*}{$\frac{\text { P-value }}{\text { Linear }}$} \\
\hline & 0 & 200 & 10 & 20 & 50 & & \\
\hline \multicolumn{8}{|l|}{ Lymphocytic cells } \\
\hline CD4 & 24.8 & 41.5 & 35.2 & 38.0 & 39.0 & 2.96 & $\mathrm{NS}^{2}$ \\
\hline $\mathrm{CD} 8$ & 6.7 & 14.7 & 11.9 & 10.3 & 7.9 & 1.29 & NS \\
\hline TCR-I & 14.4 & 12.7 & 13.7 & 13.3 & 11.8 & 0.84 & NS \\
\hline TCR-II & 17.9 & 24.9 & 18.8 & 15.9 & 20.9 & 1.87 & NS \\
\hline B-cells & 2.93 & 1.50 & 3.48 & 2.28 & 6.23 & 0.57 & NS \\
\hline
\end{tabular}

${ }^{1}$ pooled standard errors, $\mathrm{n}=4$ birds/treatment

${ }^{2}$ not significant

Chickens vaccinated with IB vaccine had significantly increased ELISA titers at $14 \mathrm{~d}$ after vaccination in $200 \mathrm{mg} / \mathrm{kg} \mathrm{VC}$ fed group (Table 8) when compared with control. ELISA titer to ND of chicken in $20 \mathrm{mg} / \mathrm{kg}$ VC-PEG group was significantly $(\mathrm{P}<0.05)$ higher than other groups at $14^{\text {th }}$ day.

TABLE 8

The effect of supplemental vitamin C on IB and ND antibody titers

\begin{tabular}{|c|c|c|c|c|c|c|c|}
\hline \multirow{2}{*}{ Treatments, $\mathrm{mg} / \mathrm{kg}$} & \multicolumn{2}{|c|}{ Vitamin C } & \multicolumn{3}{|c|}{ Polyethylene glycol -C } & \multirow{2}{*}{$\mathrm{SE}^{1}$} & \multirow{2}{*}{$\frac{\text { P-value }}{\text { Linear }}$} \\
\hline & 0 & 200 & 10 & 20 & 50 & & \\
\hline \multicolumn{8}{|l|}{ IB titers } \\
\hline $14^{\text {th }}$ day & $45^{\mathrm{c}}$ & $409^{\mathrm{a}}$ & $160^{\mathrm{ab}}$ & $321^{\mathrm{ab}}$ & $147^{\mathrm{b}}$ & 43.8 & 0.04 \\
\hline $28^{\text {th }}$ day & 161 & 199 & 170 & 288 & 151 & 24.8 & $\mathrm{NS}^{2}$ \\
\hline \multicolumn{8}{|l|}{ ND titers } \\
\hline $14^{\text {th }}$ day & $560^{\mathrm{b}}$ & $1031^{\mathrm{b}}$ & $1056^{\mathrm{b}}$ & $3141^{\mathrm{a}}$ & $1220^{\mathrm{b}}$ & 294 & 0.04 \\
\hline $28^{\text {th }}$ day & 1084 & 2386 & 1227 & 2264 & 3547 & 313 & NS \\
\hline
\end{tabular}

abc values with different superscripts in the same row differ significantly $(\mathrm{P}<0.05)$

${ }^{1}$ pooled standard errors, $\mathrm{n}=6$ birds/treatment

${ }^{2}$ not significant 


\section{DISCUSSION}

There was a trend to increase weight gain when $\mathrm{VC}$ was added in the broiler diets in present study. The results were not in agreement with the results of Sifri et al. (1977) who did not demonstrate improved growth of chickens with the addition of VC in broiler's diet, but Thaxon and Pardue (1984) obtained positive responses especially immediately after heat stress, and Kassim and Norziha (1995) also reported that ascorbic acid supplementation in broilers improved weight gain and feed efficiency in the natural hot humid tropical climate $\left(20-35^{\circ} \mathrm{C}\right)$.

As previously stated, VC is synthesized by poultry. Therefore, its requirement is not established by NRC (1994). However, biosynthesis of VC was limited in very young birds (Horning and Frigg, 1979), and several stressors were known to alter the biosynthesis and/or utilization of ascorbic acid (Pardue and Thaxton, 1986). In terms of environmental stress, high temperature is a major concern in broiler production in summer. In our study, improvement in weight gain was clearer during the starter period than the finisher period. This result supported the reports of Horning and Frigg (1979) that young chickens have lower synthetic ability of ascorbic acid. Also, we conducted this experiment in hot season in Korea.

Under high environmental temperature, bird's heat-associated mortality is increased, and the effect of VC is also increased. In a field trial (Pardue et al., 1985), the mortality was markedly reduced when 4-week old broiler chickens were exposed to $38^{\circ} \mathrm{C}$ fed with VC. Reduced mortality was also found in our study when $\mathrm{VC}$ was added in the diet (Table 2). It had been suggested that ascorbic acid might reduce glucocorticoid levels (Mckee and Harrison, 1995), and suppress heat-induced corticosteroids (Edens and Siegel, 1975) during heat stress.

In addition, improved weight gain of chickens fed diets added VC might partially be attributed to feed intake and nutrient digestibility in this study. Feed intake was linearly $(\mathrm{P}=0.01)$ increased as dietary $\mathrm{VC}$ levels were increased. Feed intake is related to body temperature in chickens. This is consistent with the results of some researchers, who reported increased feed intake in chickens fed ascorbic acid under heat stress (Kutlu and Forbes, 1993; Kassim and Norziha, 1995; Mckee and Harrison, 1995).

The digestibilities of protein and fat were higher $(\mathrm{P}<0.05)$ in $\mathrm{VC}$ added groups (50 mg/kg VC-PEG and $200 \mathrm{mg} / \mathrm{kg} \mathrm{VC}$ ) than others during starter phase in our study. The crude protein and fat digestibility was also higher in 10 and $20 \mathrm{mg} / \mathrm{kg}$ VC supplemented diets, when compared to non-supplemented group in our earlier studies conducted during finisher phase in broilers (Lohakare et al., 2004) There is, however, no evidence why nutrient digestibility is improved when $\mathrm{VC}$ is added in the diet. Sahin and Kucuk $(2001)$ also reported greater $(\mathrm{P}<0.02)$ digestibility of DM, OM, CP and EE when fed higher dietary vitamin $\mathrm{C}$ at the level of 
$200 \mathrm{mg} / \mathrm{kg}$ diet to Japanese quails reared under chronic heat stress $\left(34^{\circ} \mathrm{C}\right)$. Sahin and Sahin (2002) found increased $\mathrm{N}$ retention and decreased $\mathrm{N}$ excretion of laying hens reared at a low ambient temperature $\left(7^{\circ} \mathrm{C}\right)$ when fed $\mathrm{VC}$ at a level of $250 \mathrm{mg} /$ $\mathrm{kg}$ diet when compared with non-supplemented diet. Scanty reports are available with respect to effect of $\mathrm{VC}$ on nutrient digestibility.

$\mathrm{VC}$ is necessary for bone development and eggshell quality, as a cofactor for the bioconversion of vitamin $\mathrm{D}_{3}$ to its active form of $1,25(\mathrm{OH})_{2} \mathrm{D}_{3}(\mathrm{McDowell}$, 2000). In the present study, bone strength was higher $(\mathrm{P}=0.0001)$ as dietary VC level was increased. Calcium and phosphorus contents in tibia from chickens fed diets containing VC were higher than control, though it was not statistically significant. Sergeev et al. (1990) reported first time that ascorbic acid plays a critical role in vitamin D metabolism and binding in guinea pigs. The effects occur both at a level of vitamin D hormone formation in kidneys and it's binding in target tissue. VC is a cofactor, for several key enzymes, involved in procollagen synthesis (Tillman, 1993). More specifically, VC aids the enzymes required to convert peptide bound proline and lysine into hydroxyproline and hydroxylysine, respectively. These conversions are necessary for controlled formation of collagen. The collagen fibril network, which is required for proper bone formation has to be mineralized with hydroxyapatite. This mineralization process is under the direct influence of the active metabolites of vitamin $\mathrm{D}_{3}$. Metabolism of calcium has also been reported to be influenced by dietary ascorbic acid (Thornton, 1970; Dorr and Balloun, 1976; Orban et al., 1993) and the binding capacity of calcium binding proteins was significantly improved with VC supplementation. The increased collagen synthesis and increased mineralization must have increased the bone breaking strength in VC supplemented diet at $200 \mathrm{mg} / \mathrm{kg}$ level in our study. This was also confirmed from the crude ash content estimated which was higher. Since the intake and digestibility of the nutrients was higher in $\mathrm{VC}$ supplemented groups the bioavailability and its content increases in the bone and it was also reflected in the plasma and liver content of VC (Table 6).

There were no differences in dressing percentage, breast meat and abdominal fat percentages among treatments. In chicken meat colours, however, ' $a$ ' value (redness) was significantly ( $\mathrm{P}=0.03$ ) increased, and ' $\mathrm{b}$ ' value (yellowness) was linearly $(\mathrm{P}=0.001)$ decreased as dietary $\mathrm{VC}$ level was increased in the diet. This means that the colour stability was improved by the addition of $\mathrm{VC}$ as an antioxidant agent. It took $6 \mathrm{~h}$ to prepare and measure the colour after slaughtering the birds, suggesting lipid oxidation was somewhat progressed. Lipid oxidation affects the formation of oxidized pigment such as metmyoglobin. This meaned that the colour stability was improved in present study by the addition of $\mathrm{VC}$ as an antioxidant agent and the higher values in non-supplemented group is suggestive of lipid peroxidation has somewhat progressed. The muscle oxymyoglobin oxidized 
in the presence of oxidizing lipids and the undesirable brown discolouration results, which was prevented by supplemental VC levels.

$\mathrm{VC}$ concentrations in plasma and liver were linearly increased as dietary $\mathrm{VC}$ levels were increased ( $\mathrm{P}=0.02$ for plasma and $\mathrm{P}=0.05$ for liver; Table 6). Plasma ascorbic acid level in the fowl is easily influenced by exogenously administered ascorbic acid (Pardue and Thaxton, 1986). The data of VC content in plasma revealed significantly $(\mathrm{P}<0.05)$ higher levels in $\mathrm{VC}$ supplemented diets as compared with non-supplemented one. In our study, as the level of supplementation increased, the levels in plasma and liver also increased linearly. A significant positive trend was noticed with the levels supplied and their levels in plasma and liver. Because ascorbic acid is actively transported into tissues and its utilization increases during period of stress like heat, the birds synthetic capacity may become inefficient reducing plasma ascorbic acid concentrations which was found in non-supplemented groups. The efficacy of supplementing birds with $\mathrm{VC}$ under stressful conditions therefore depends on its ability to elevate plasma ascorbic acid concentrations, thereby preventing tissue depletion. Ascorbic acid either decreases heat load by lowering heat production or increase heat loss by influencing avenues of thermal exchange between the body and the environment as suggested by Chang et al. (1993).

The CD4, CD8, TCR-I, TCR-II and B cells were not affected by VC supplementation. The B cells population was lowest as compared to other lymphocyte cells in chickens. Apparently, dietary VC supplementation had no effect on lymphocyte populations when compared to non-supplemented one. The possible effect of less impact of supplementation in our study may be the age as we conducted study at 4 weeks of age, since Erf et al. (1998) found less apparent effects of vitamin E supplementation on T cell differentiation than at 7 weeks old chickens. Scanty reports are available with respect to effect of VC on lymphocyte subpopulation. Further studies needs to be done to see the effect of VC supplementation on lymphocyte subpopulations.

The IB and ND vaccination was done at 18 days of age and the titers were measured after 14 and 28 days post vaccination in 6 chickens per group. The ELISA titers to IB were higher significantly $(\mathrm{P}=0.04)$ at $14^{\text {th }}$ day of measurement in 200 $\mathrm{mg} / \mathrm{kg} \mathrm{VC} \mathrm{fed} \mathrm{group} \mathrm{and} \mathrm{the} \mathrm{lowest} \mathrm{in} \mathrm{non-supplemented} \mathrm{group} \mathrm{(Table} \mathrm{8),} \mathrm{but} \mathrm{it}$ was not significantly higher in $200 \mathrm{mg} / \mathrm{kg} \mathrm{VC}$ fed chickens at $28^{\text {th }}$ day. The ND titers were significantly influenced at $14^{\text {th }}$ day of measurement by VC supplementation at $20 \mathrm{mg} / \mathrm{kg}$ VC-PEG level. The results are in agreement with that of Tuekam et al. (1994) who found increased antibody titers to IB vaccine in chickens fed 500 $\mathrm{mg} / \mathrm{kg}$ VC. Similar response of increased antibody response of chickens to sheep red blood cells and infectious bursal disease at $1000 \mathrm{ppm}$ supplementation was also noted by Pardue et al. (1985) and Amakye-Anim et al. (2000). Dieter and 
Breitenbach (1971) postulated the possibility of increasing antibody to vaccination in VC supplemented chickens compared to non-supplemented one, may be due to speeding up of differentiation of lymphoid organs by increasing the activity of hexose monophosphate pathway, thus increasing circulating antibody.

Overall it could be concluded that VC supplementation at higher levels (200 $\mathrm{mg} / \mathrm{kg}$ ) is beneficial for broilers during heat stress to improve the performance and immunity. Also VC supplemented in polyethylene glycol complex form at 50 $\mathrm{mg} / \mathrm{kg}$ was proven beneficial to improve the performance at par with $200 \mathrm{mg} / \mathrm{kg}$ VC levels.

\section{CONCLUSIONS}

The present study was conducted to evaluate the effect of VC under heat stress, when given in either polyethylene glycol complex form and as ascorbate at 200 $\mathrm{mg} / \mathrm{kg}$, on the performance, meat quality and immunity of broilers. The PEG form at $50 \mathrm{mg} / \mathrm{kg}$ performed at par with that of $200 \mathrm{mg} / \mathrm{kg}$ VC fed group. The study revealed that supplementation of $\mathrm{VC}$ is beneficial to broilers during heat stress and it also maintained the meat quality and immunity of broilers.

\section{REFERENCES}

Amakye-Anim J., Lin T.L., Hester P.Y., Thiagarajan D., Watkins B.A., Wu C.C., 2000. Ascorbic acid supplementation improved antibody response to infectious bursal disease vaccination in chickens. Poultry Sci. 79, 680-688

AOAC, 1990. Official Method of Analysis, Association of Official Analytical Chemists. $15^{\text {th }}$ Edition. Arlington, VA

Chae B.J., Lohakare J.D., Choi J.Y., Han K.N., Yong J.S., Won H.K., Park Y.H., Hahn T.-W., 2005. The efficacy of vitamin E-polyethylene glycol complex on growth performance, chicken meat quality and immunity in broilers. J. Anim. Feed Sci. 14, 125-138

Chang K.C., Chong W.S., Sohn D., Kwon B.H., Lee I.J., Kim C.Y., Yang J.S., Joo J.I., 1993. Endothelial potentiation of relaxation response to ascorbic acid in rat and guinea pig thoracic aorta. Life Sci. 52, 37-42

Davis W. C., Hamilton M. J., Park Y. H., Larsen R. A., Wyatt C. R., Okada K., 1990. Ruminant leukocyte differentiation molecules. MHC, differentiation antigens and cytokines in animals and birds. Monographs Anim. Immunol. 1, 47-70

Dieter M.P., Breitenbach R.P., 1971. Vitamin C in lymphoid organs of rats and cockerel treated with corticosterone or testosterone. Proc. Soc. Exp. Biol. Med. 137, 341-346

Dorr P., Balloun S. L., 1976. Effect of dietary vitamin A, ascorbic acid and their interaction on turkey bone mineralisation. Brit. Poultry Sci. 17, 581-599

Edens F.W., Siegel H.S., 1975. Adrenal responses in high and low ACTH response lines of chickens during acute heat stress. Gen. Comp. Endocrinol. 25, 64-73 
Erf G.F., Bottje W.G., Bersi T.K., Headrick M.D., Fritts C.A., 1998. Effects of dietary vitamin E on the immune system in broilers: Altered proportions of CD4 T cells in the thymus and spleen. Poultry Sci. 77, 529-537

Gross W. B., 1988. Effect of environmental stress on the responses of ascorbic-acid-treated chickens to Escherichia coli challenge infection. Avian Dis. 32, 432-436

Horning M. P., Frigg M., 1979. Effects of age on biosynthesis of ascorbate in chicks. Arch. Geflügelk. 43, 108-112

Kassim H., Norziha I., 1995. Effects of ascorbic acid (vitamin C) supplementation in layer and broiler diets in the tropics. Asian-Austr. J. Anim. Sci. 8, 607-610

Kutlu H. R., Forbes J. M., 1993. Effect of changes in environmental temperature on self-selection of ascorbic acid in colored feeds by broiler chicks. Proc. Nutr. Soc. 52, 29A

LG Chemicals Co. Report., 2000. A Brochure of Product Information. LG Life Sciences Ltd., Seoul (Korea)

Lohakare J.D., Chae B. J., Hahn T.-W., 2004. Effects of feeding methods (water versus feed) of vitamin $\mathrm{C}$ on growth performance and carcass characteristics in broiler chicken. Asian-Austr. J. Anim Sci. 17, 1112-1117

McDowell L. R. (Editor), 2000. Vitamins in Animal and Human Nutrition. $2^{\text {nd }}$ Edition. Iowa State University Press. Ames, Iowa

Mckee J.S., Harrison P.C., 1995. Effects of supplemental ascorbic acid on the performance of broiler chickens exposed to multiple concurrent stressors. Poultry Sci. 74, 1772-1785

National Research Council, 1994. Nutrient Requirements of Poultry. $9^{\text {th }}$ revised Edition. National Academy Press. Washington, DC

Orban J.I., Roland D.A., Cummins K., Lovell R.T., 1993. Influence of large doses of ascorbic acid on performance, plasma calcium, bone characteristics and egg shell quality in broilers and leghorn hens. Poultry Sci. 72, 691-700

Pardue S.L., Thaxton J.P., Brake J., 1985. Role of ascorbic acid in chicks exposed to high environmental temperature. J. Appl. Physiol. 58, 1511-1516

Pardue S.L., Thaxton J.P., 1986. Ascorbic acid in poultry: a review. World Poultry Sci. J. 42, 107-123

Sahin K., Kucuk O., 2001. Effects of vitamin C and vitamin E on performance, digestion of nutrients, and carcass characteristics of Japanese quails reared under chronic heat stress $\left(34^{\circ} \mathrm{C}\right)$. J. Anim. Physiol. Anim. Nutr. 85, 335-342

Sahin K., Sahin N., 2002. Effects of chromium picolinate and ascorbic acid dietary supplementation on nitrogen and mineral excretion of laying hens reared in a low ambient temperature $\left(7^{\circ} \mathrm{C}\right)$. Acta Vet. Brno 71, 183-189

SAS Institute., 1985. SAS User's Guide: Statistics. SAS Institute Inc., Cary NC

Sergeev I.N., Arkhapchev Y.P., Spirichev V.D., 1990. Ascorbic acid effects on vitamin D hormone metabolism and binding in guinea pigs. J. Nutr. 120, 1185-1190

Sifri M., Kratzer F.H., Norris L.C., 1977. Lack of effect of ascorbic and citric acids on calcium metabolism of chickens. J. Nutr. 107, 1484-1492

Thaxton J.P., Pardue S.L., 1984. Ascorbic acid and physiological stress. In: Proceedings of Ascorbic Acid in Domestic Animals. The Royal Danish Agricultural Society, Copenhagen, pp. 25-31

Thornton P.A., 1970. Influence of exogenous ascorbic acid on calcium and phosphorus metabolism in the chick. J. Nutr. 100, 1479-1486

Tillman P.B., 1993. Vitamin C for laying hens: A review. Multi-State Poultry Feeding and Nutrition Conference, Indianapolis, Indiana

Tuekam T.D., Miles R.D., Butler G.D., 1994. Performance and humoral immune response in heatstressed broilers fed an ascorbic acid supplementation. J. Appl. Anim. Res. 6, 121-130

Zulkifli I., Ramlah A. H., Vidyadaran M. K., Rasedee A., 1996. Dietary ascorbic acid: Self selection and response to high temperature and humidity in broilers. Malay. Appl. Biol. 25, 93-101 


\section{STRESZCZENIE}

\section{Wpływ kompleksu witamina C - glikol polietylenowy na wzrost i odporność kurcząt brojlerów}

W 6-tygodniowym doświadczeniu badano wpływ kompleksu witamina C-glikol polietylenowy (VC-PEG) na wzrost i odporność u kurcząt w warunkach stresu cieplnego. Trzysta trzydzieści kurcząt-brojlerów podzielono na 5 grup doświadczalnych, stosując następujące dodatki, $\mathrm{mg} / \mathrm{kg}$ : 1. 0 witaminy $\mathrm{C}(\mathrm{VC})$ (negatywna kontrola), 2. $200 \mathrm{VC}$ w postaci askorbinianu (pozytywna kontrola), 3. 10 VC-PEG, 4. 20 VC-PEG, i 5. 50 VC-PEG. Na końcu doświadczenia ubito po 9 kurcząt $\mathrm{z}$ grupy w celu oznaczenia zawartości VC w krwi i wątrobie oraz jakości mięsa. W okresie skarmiania mieszanki starter przyrosty kurcząt z grupy 1 (kontrola negatywna) były gorsze $(\mathrm{P}<0,05)$ niż $\mathrm{z}$ pozostałych grup, a w ciagu całego doświadczenia przyrosty kurcząt $\mathrm{z}$ grupy 1 i $3(10 \mathrm{mg} / \mathrm{kg}$ VC-PEG) były gorsze niż w pozostałych. Stężenie VC w plazmie krwi i wątrobie kurcząt otrzymujących diety z dodatkiem witaminy było wyższe niż żywionych dietą bez VC. Wytrzymałość kości zwiększała się w miarę wzrostu poziomu VC w diecie (zależność liniowa, $\mathrm{P}=0,001)$.

Nie stwierdzono wpływu dodatku zastosowanego kompleksu na subpopulację limfocytów. Tworzenie przeciwciał przeciw chorobie Newcastle i zakażeniu oskrzeli było większe u kurcząt z grupy 4 (20 mg/kg VC-PEG) niż w pozostałych grupach otrzymujących ten dodatek.

W podsumowaniu stwierdzono, że dodatek witaminy $\mathrm{C}$ do diet ma korzystny wpływ na kurczęta w warunkach stresu cieplnego. 